\title{
Evaluation of fluorescence in situ hybridisation (FISH) for the detection of fungi directly from blood cultures and cerebrospinal fluid from patients with suspected invasive mycoses
}

\author{
Roberto Moreira Da Silva Jr' , João Ricardo Da Silva Neto², Carla Silvana Santos², Hagen Frickmann ${ }^{3}$, Sven Poppert ${ }^{4}$,
} Kátia Santana Cruz ${ }^{2}$, Daniela Koshikene ${ }^{5}$ and João Vicente Braga De Souza ${ }^{6,7^{*}}$

\begin{abstract}
The aim of this study was to evaluate the diagnostic performance of in-house FISH (fluorescence in situ hybridisation) procedures for the direct identification of invasive fungal infections in blood cultures and cerebrospinal fluid (CSF) samples and to compare these FISH results with those obtained using traditional microbiological techniques and PCR targeting of the ITS1 region of the rRNA gene. In total, 112 CSF samples and 30 positive blood cultures were investigated by microscopic examination, culture, PCR-RFLP and FISH. The sensitivity of FISH for fungal infections in CSF proved to be slightly better than that of conventional microscopy (India ink) under the experimental conditions, detecting 48 (instead of 46) infections in 112 samples. The discriminatory powers of traditional microbiology, PCR-RFLP and FISH for fungal bloodstream infections were equivalent, with the detection of 14 fungal infections in 30 samples. However, the mean times to diagnosis after the detection of microbial growth by automated blood culture systems were 5 hours, 20 hours and 6 days for FISH, PCR-RFLP and traditional microbiology, respectively. The results demonstrate that FISH is a valuable tool for the identification of invasive mycoses that can be implemented in the diagnostic routine of hospital laboratories.
\end{abstract}

Keywords: FISH, Invasive mycoses, CSF, Blood culture, rRNA, Hybridisation

\section{Introduction}

The number of invasive fungal infections has increased over the last few decades. This phenomenon is the result of the growing number of pathological or iatrogenic immunocompromising conditions, premature births, neoplasms, abdominal surgeries, medical device insertion procedures and antibiotic therapies [1,2].

In northern Brazil, specifically in the state of Amazonas, histoplasmosis and cryptococcosis are some of the most frequent causes of death in AIDS patients [3], and candidemia is a problem in neonatal intensive care units [4]. In northern Brazil, the current diagnostic procedures at the

\footnotetext{
* Correspondence: joao.souza@inpa.gov.br

'Instituto Nacional de Pesquisas da Amazônia, Manaus, Brazil

${ }^{7}$ Biotecnólogo/Tecnologista Pleno III, Instituto Nacional de Pesquisas da Amazônia, Coordenação de Sociedade, Ambiente e Saúde, Laboratório de Micologia, Av. André Araújo, 2936, Aleixo, Manaus, AM CEP 69060-001, Brazil Full list of author information is available at the end of the article
}

hospital laboratories for the detection and identification of invasive fungal infections include culture (blood cultures, clinical specimens cultured on selective fungal media), biochemical methods, microscopic morphological determination and immunological assays. However, these traditional methods are time consuming, and their sensitivity for early detection is low [5]. To overcome these limitations, molecular approaches can be used for the detection and identification of pathogenic fungi [6].

Molecular techniques, particularly PCR-based approaches, have been developed to detect fungi in a short period of time; these approaches include nested PCR, multiplex PCR, real-time PCR and microarray techniques [7]. Although they have shown convincing results, the assays remain expensive, and definitive results are guaranteed only after several hours of hands-on time by highly experienced microbiologists [7-9]. 
Fluorescence in situ hybridisation (FISH) has already been successfully implemented in clinical microbiology for the identification of various pathogens, including fungi [10-15]. The hybridisation of fixed fungi with fluorescently labelled oligonucleotide probes that are complementary to unique target sites on the ribosomal RNA allows direct microscopic visualisation without prior amplification steps, even from blood culture smears. As an alternative to DNA-based FISH probes, peptide nucleic acid (PNA) probes with a neutral backbone may be used, although these probes are considerably more expensive $[10,12]$.

The literature contains several studies that have evaluated FISH for the detection and identification of Candida spp. $[12,16,17]$ and for the detection of pathogenic Cryptococcus ssp. [14]. This study is the first demonstration of the application of FISH for the routine identification of the primary causative agents of invasive fungal infections in a diagnostic laboratory in South America. The aim of this study was to evaluate FISH for the identification of fungi directly from positive blood cultures and cerebrospinal fluid samples of patients with suspected invasive mycosis.

\section{Materials and methods Biological samples}

Samples were collected from patients who had been referred to the Mycology Laboratory of the Fundação de Medicina Tropical Dr. Heitor Vieira Dourado, Manaus, Brazil (FMT-HVD) between November 2013 and April 2014. In total, 142 biological samples were investigated, including 112 cerebrospinal fluid (CSF) samples from patients with a clinical diagnosis of cryptococcosis and 30 blood cultures that had presented positive results $\left(\mathrm{CO}_{2}\right.$ production) in a blood culture system BACTEC 9120 (Becton-Dickinson, Sparks, MD, USA); however, these blood samples were negative for bacteria according to Gram stain analysis. Anonymised patient information (sex, age, place of residence, clinical specimen investigated, HIV serology results, HIV viral load and $\mathrm{CD} 4^{+}$cell count) was obtained from the computerised system "iDoctor Hospital", which is used at FMT-HVD.

\section{Detection and identification of pathogenic fungi by conventional methods}

The detection and identification of pathogenic fungi were performed using traditional biochemical and micromorphological identification methods as previously described [18]. Initially, the CSF samples were centrifuged ( $5000 \times \mathrm{g}$ per $15 \mathrm{~min})$, and the supernatant $(90 \%$ of the initial volume) was carefully removed. Slides for direct microscopic examination were prepared with samples $(20-50 \mu \mathrm{L})$ of CSF following centrifugation $(5000 \times \mathrm{g}$, $5 \mathrm{~min}$ ) and of blood cultures (without any previous treatment). India ink was used for the visualisation of Cryptococcus spp. capsules, and lactophenol cotton blue and $10 \%$ potassium hydroxide $(\mathrm{KOH})$ were used for the visualisation of general fungal cells. Cultures from 100$200 \mu \mathrm{L}$ samples (CSF and blood culture) were grown using Sabouraud agar (BD Difco, Sparks, USA) and Mycosel agar (BD Difco, Sparks, USA). The fungal cultures were inoculated on Niger seed agar and CHROMagar ${ }^{\text {th }}$ Candida selective media (BD Difco, Sparks, USA). When the selective media were insufficient for the determination of the pathogens' species, the isolates were subsequently subjected to micro-morphological and physiological tests using the fungal identification kit API20 (bioMérieux Vitek, Inc., Hazelwood, MO, USA).

\section{Detection and identification of pathogenic fungi by PCR-RFLP}

PCR product generation and subsequent digestion for RFLP analysis was performed as described by Santos [19]. DNA was extracted from $200 \mu \mathrm{L}$ biological samples using a QIAamp Blood and Tissue Kit (Qiagen, Hilden, Germany) according to the manufacturer's instructions. The DNA was quantified by absorbance at $260 \mathrm{~nm}$ using a GeneQuant spectrophotometer (Eppendorf, Hamburg, Germany). Twenty nanograms of the extracted DNA served as template for PCR amplification. PCR reactions were performed in a total volume of $25 \mu \mathrm{L}$ containing PCR buffer (final concentration: 1x; $10 \mathrm{mM}$ Tris- $\mathrm{HCl}$ (pH 8.3) and $50 \mathrm{mM} \mathrm{KCl}), 1.5 \mathrm{mM} \mathrm{MgCl}_{2}, 200 \mathrm{nM}$ of the primers ITS5 (5' -GGAAGTAAAAGTCGTAACAAGG-3') and NL4 (5'-GGTCCGTGTTTCAAGACGG-3') (both primers were described previously by Irobi et al. [20]), $50 \mu \mathrm{M}$ dNTPs, and $1 \mathrm{U}$ ampli-Taq DNA polymerase. PCR was performed using a thermocycler (Kyratec SuperCycler, Seoul, South Korea) with the following conditions: initial denaturation for $5 \mathrm{~min}$ at $94^{\circ} \mathrm{C}$, followed by 40 cycles for $30 \mathrm{~s}$ at $94^{\circ} \mathrm{C}$ (denaturation), $30 \mathrm{~s}$ at $50^{\circ} \mathrm{C}$ (annealing), and $90 \mathrm{~s}$ at $72^{\circ} \mathrm{C}$ (extension), with a final extension for $10 \mathrm{~min}$ at $72^{\circ} \mathrm{C}$. The PCR products were visualised by electrophoresis on a $2 \%$ agarose gel and stained with $\mathrm{SYBR}^{\circ}$ Green (SYBR Safe DNA Gel Stain, Invitrogen, Carlsbad, CA, USA). A DNA Ladder Mix (SM0331, MBI Fermentas, St. Leon-Rot, Germany) served as the size marker. The positive PCR products were identified using RFLP. The amplicons were digested with $10 \mathrm{U}$ of the restriction enzyme DdeI (Thermo Fisher Scientific, Vilnius, Lithuania) for $3 \mathrm{~h}$ at $37^{\circ} \mathrm{C}$ and subjected to electrophoresis as described above. The sizes of the PCR products and restriction fragments generated from the isolates were compared with the corresponding previously described nucleotide sequences [20].

\section{Detection and identification of pathogenic fungi by FISH}

The initial FISH reaction was performed using the panfungal probe, and then specific probes for each fungal 
species were used when fungal structures were found. These probes were chosen because of their high specificity and because of the absence of cross-reactions with other fungal species. The details of each probe used in the present study are presented in Table 1 . In addition to the probes, the samples were counterstained with DAPI (4',6-diamidino-2-phenylindole-dihydrochloride).

The CSF samples were centrifuged at $10000 \times g$ for $5 \mathrm{~min}$ at room temperature. The pellet containing cells was washed with $500 \mu \mathrm{L}$ of phosphate-buffered saline (PBS; $130 \mathrm{mM}$ sodium chloride and $10 \mathrm{mM}$ sodium phosphate buffer ( $\mathrm{pH} 7.2)$ ) and fixed for $4 \mathrm{~h}$ with $4 \% \mathrm{w} / \mathrm{v}$ paraformaldehyde in PBS at $4^{\circ} \mathrm{C}$. After fixation, the cells were washed twice with PBS, suspended in one volume of PBS and one volume of cold absolute ethanol and stored at $-20^{\circ} \mathrm{C}$ until use.

For the investigation of pre-incubated blood cultures, $0.5 \mathrm{ml}$ acetic acid (100\%) was added to $5 \mathrm{ml}$ blood culture medium to lyse the erythrocytes. The suspension was centrifuged at $10000 \times g$ for $5 \mathrm{~min}$. Then, the supernatant was discarded, and the pellet containing cells was treated following the same procedures described for treating the pellet obtained with CSF samples.

The FISH assay was performed as described by Amann [24]. The whole fixed cells were smeared onto precleaned microscopic slides and dried at $37^{\circ} \mathrm{C}$ for $20 \mathrm{~min}$. Next, the slides were covered with hybridisation buffer $(0.9 \mathrm{M} \mathrm{NaCl}, \quad 0.01 \%$ w/v SDS, $20 \mathrm{mM}$ Tris-HCl ( $\mathrm{pH}$ 7.2), formamide and $1 \mu \mathrm{M}$ probe) and incubated at $46^{\circ} \mathrm{C}$ for $2 \mathrm{~h}$. After this period, the slides were washed with wash buffer (20 mM Tris- $\mathrm{HCl}(\mathrm{pH} 8.0), 0.01 \% \mathrm{w} / \mathrm{v}$ SDS, $5 \mathrm{mM}$ EDTA and $\mathrm{NaCl}$ ) for $30 \mathrm{~min}$ at $46^{\circ} \mathrm{C}$. The concentrations of formamide and $\mathrm{NaCl}$ in the hybridisation buffer and wash buffer, respectively, varied according to the probe (Table 1). Then, the slides were dried at $37^{\circ} \mathrm{C}$ for $20 \mathrm{~min}$, mounted in Vectashield solution (Vector, Burlingame, CA, USA) and examined using a Zeiss Axioskop 40 microscope (Zeiss, Jena, Germany).

\section{Ethical considerations}

Ethical clearance for this study was obtained from the Ethical Committee at the Fundação de Medicina Tropical Heito Viera Dourado in accordance with Brazilian laws relating to research with human subjects.

\section{Results}

Conventional microscopy (India ink) and FISH were performed to confirm or exclude the presence of fungal agents in 112 CSF samples from patients with the clinical suspicion of cryptococcosis. Table 2 displays the calculated sensitivities and specificities of the culture, conventional microscopy and FISH analyses, using PCR for detecting yeast from the Cryptococcus neoformans complex, which includes C. neoformans and C. gattii, in cerebrospinal fluid as a reference. In total, 46 CSF samples tested positive by both conventional microscopy and FISH. In contrast, 2 samples tested positive by FISH and PCR but negative by conventional microscopy.

Thirty blood cultures were investigated, and 14 showed positive results with traditional microbiological approaches and with PCR-RFLP and FISH analyses. The identified pathogens included the $C$. neoformans complex $(\mathrm{n}=8)$, Histoplasma capsulatum $(\mathrm{n}=2)$ and Candida albicans $(n=4)$. Traditional microbiological approaches and PCR-RFLP and FISH analyses showed identical results for the blood culture materials. However, the mean times to diagnosis after the detection of microbial growth in the automated blood culture system were 5 hours, 20 hours and 6 days for detection by FISH, PCR-RFLP and traditional microbiological approaches, respectively. Selected FISH images of the identified microorganisms are shown in Figure 1. The patients presenting invasive mycoses included 9 males and 5 females between 12 and 54 years of age. Nine patients were serologically positive for HIV, with viral loads between 75.098 and 554.987 copies $/ \mathrm{ml}$ and with $\mathrm{CD}^{+}$cell counts between 211 and $669 \mathrm{CD}^{+}$lymphocytes $/ \mathrm{ml}$.

Table 1 Information regarding the probes used in the present study

\begin{tabular}{|c|c|c|c|c|c|}
\hline Target microorganisms & Probes & Sequences $\left(5^{\prime}-3^{\prime}\right)$ & $\begin{array}{l}\text { Formamide content in } \\
\text { hybridisation buffer }(\% \mathrm{v} / \mathrm{v})\end{array}$ & $\begin{array}{l}\mathrm{NaCl} \text { content in } \\
\text { wash buffer (M) }\end{array}$ & Authors \\
\hline C. albicans & Caal $^{*}$ & GCCAAGGCTTATACTCGCT & 30 & 0.112 & Kempf [10] \\
\hline C. glabrata & Cagl* $^{*}$ & CCG CCA AGC CAC AAG GAC T & 30 & 0.112 & Kempf [10] \\
\hline C. parapsilosis & Сара* & CCTGGTTCGCCAAAAAGGC & 20 & 0.225 & Kempf [10] \\
\hline Aspergillus spp. & Asp* & TGATACATTCCGAG & 25 & 0.159 & Wang [21] \\
\hline C. neoformans and C. gattii & Cne205* & CCAGCCCTTATCCACCGA & 20 & 0.225 & Martins [14] \\
\hline H. capsulatum & $\mathrm{Hca}^{*}$ & AGTCGAGGCTTTCAGCATGT & 30 & 1.112 & Silva Jr [22] \\
\hline Fungi & Pan fungal** & CTCTGGCTTCACCCTATTC & 30 & 0.112 & Amann [23] \\
\hline
\end{tabular}

*Oligonucleotide probe synthesised and directly 5'-labelled with the hydrophilic sulphoindocyanine fluorescent dye Cy3 (Thermo Hybaid, Ulm, Germany).

**Oligonucleotide probe synthesised and directly 5'-labelled with fluorescein isothiocyanate (FITC) (Thermo Hybaid, Ulm, Germany). 
Table 2 Sensitivity and specificity of culture, microscopy and FISH analyses as calculated using PCR as the gold standard for the detection of C. neoformans and C. gattii in CSF

\begin{tabular}{lllll}
\hline & & \multicolumn{2}{l}{ PCR } \\
\cline { 3 - 4 } \cline { 3 - 4 } $\begin{array}{llll}\text { Tests compared } \\
\text { to PCR }\end{array}$ & FISH & Positive & Negative \\
& & 48 & 0 \\
& & Negative & 0 & 64 \\
& Sensitivity (\%) & & 100 & \\
& Specificity (\%) & 100 & \\
& Microscopy (Direct & Positive & 46 & 0 \\
examination) & Negative & 2 & 64 \\
& Sensitivity (\%) & & 95.8 & \\
& Specificity (\%) & & 100 & \\
& Culture & Positive & 41 & 0 \\
& Segative & 5 & 66 \\
& & 89.1 & \\
& Specificity (\%) & 100 & \\
\hline
\end{tabular}

\section{Discussion}

The present work demonstrated the application of FISH for the routine detection of the primary causative agents of invasive fungal infections in patients in a diagnostic laboratory in South America. Molecular methods, including PCR and FISH, have been developed for the rapid identification of fungal agents from primary sample materials. FISH is a comparatively inexpensive and easy-to-perform molecular method that has already been successfully implemented in clinical microbiology for the identification of pathogenic species of Candida and Cryptococcus [13,16,25].

The sensitivity of FISH for fungal infections in CSF proved to be slightly better than conventional microscopy (India ink) under the experimental conditions and allowed the detection of two cryptococcosis patients who were missed by conventional microscopy. Martins et al. [14] also demonstrated that FISH presented better results than India Ink microscopy under their experimental conditions. FISH most likely allowed the detection of fungi cells that had an altered capsular appearance caused by antifungal treatment [26], while India Ink microscopy did not. A multi-centric approach to obtain the numbers of respective samples needed to perform a statistical comparison is now necessary.

Fourteen blood cultures from patients with suspected systemic fungal infections showed positive results. The traditional microbiological approaches and PCR-RFLP and FISH analyses gave the same results in terms of the detection (100\% sensitivity) and identification of the fungal agents. However, traditional microbiological assays require the sub-culturing of blood culture samples; microscopic assays, including India ink, lactophenol cotton blue and
Gram staining; and biochemical assays, including sugar assimilation, sugar fermentation and enzyme production tests. These assays are slow, requiring 3-10 days and trained microbiologists. PCR-RFLP requires DNA extraction, PCR and electrophoresis to assess the PCR products. In addition, the PCR products must be digested by restriction enzymes, and the RFLP profiles must be evaluated. These steps require at least 20 hours and trained staff with experience in molecular techniques. FISH is robust, easier to perform, and considerably faster, with a time-to-result of up to 5 hours.

In addition to these results, FISH demonstrated the capability of identifying the fungi directly in the biological samples and did not require sub-cultures; these characteristics are essential for conventional diagnoses. This capability is a great advantage for histoplasmosis diagnosis because $\mathrm{H}$. capsulatum cultures should be manipulated under high biosafety containment conditions [27]. Notably, the present study is the first demonstration of the possibility of FISH using combinations of these six adopted probes.

In the present work, 16 blood cultures presented "microbial growth" in the blood culture system but did not present bacterial (Gram stain) or fungal growth (traditional microbiological assays, FISH and PCR). The false detection of microbial growth by blood culture systems has been previously described [28]. The simultaneous lack of detection by FISH and by the other techniques (PCR-RFLP and culture) demonstrated the adequate specificity of the FISH technique.

Regarding the limitations of the present study, we did not use latex agglutination tests to investigate the presence of cryptococcal polysaccharide antigen in the CSF samples. However, Martins et al. [14] developed the Cryptococcus probes that were used in the present work and demonstrated that FISH and the latex agglutination test present similar results when these probes were used. Another limitation is that the combination of probes in this paper did not cover other possible pathogens; however, this limitation was mitigated because the choice of probes used was based on research by Souza et al. [14], who demonstrated the predominant species of fungi that cause invasive mycoses in patients in northern Brazil.

Previous studies have demonstrated that FISH is a useful tool for environmental microbiology studies [23]. The improvement of this technology (the utilisation of enzymes and PNA probes and the association with flow cytometry) motivated the development of several works in clinical microbiology $[6,16,17,25,29,30]$. Specifically in medical mycology, the detection of Candida spp. motivated most of these studies and resulted in the production of commercial kits [16]. Recently, FISH probes were developed for detecting Cryptococcus spp. [14] and H. capsulatum [21]. Additionally, these studies have clearly demonstrated that the FISH technique is more effective with biological samples 

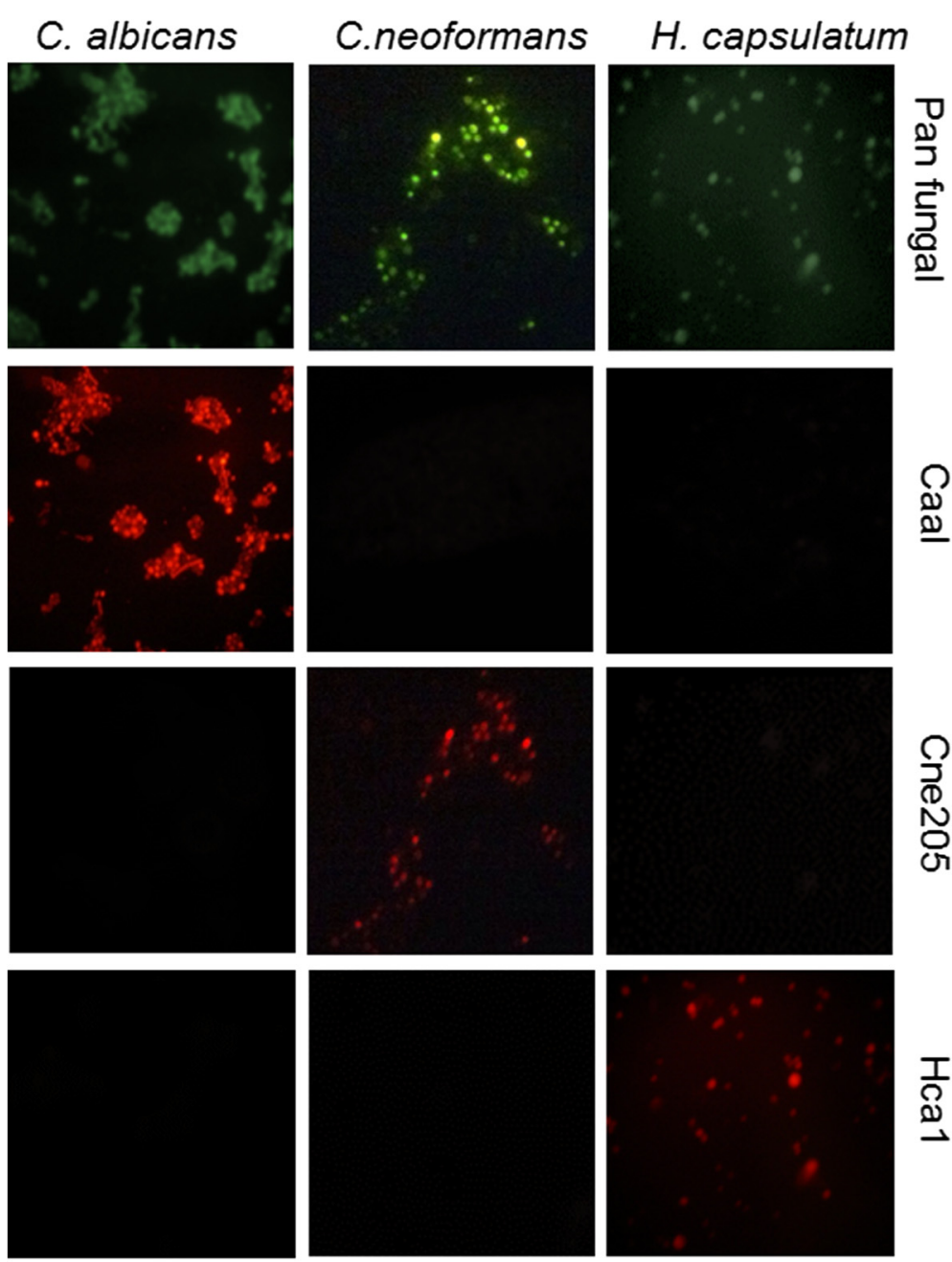

$-10 \mu \mathrm{m}$

Figure 1 Fluorescence microscopy of microorganisms after FISH with various oligonucleotide probes. C. albicans, C. neformans and H. capsulatum (vertical columns) were stained with FISH with probes Pan Fungal (green signal; specific for all fungi) and Caal (specific for C. albicans), Cne 205 (specific for C. neoformans and C. gattii), and Hcal (specific for H. capsulatum), each Cy3 labelled (red signal).

that present high fungal cell contents, such as the specimens that were selected for the present work.

This study is the first to assess the detection and identification of important fungal agents, i.e., Candida spp., Cryptococcus spp. and H. capsulatum, using the routine procedures of an infectious disease hospital in South America. These results suggest that FISH is a valuable, robust, fast and easy to perform tool that can be readily implemented in the diagnostic routine of hospital laboratories.

\section{Competing interests}

The authors declare that they have no competing interest exists.

\section{Authors' contributions}

JVBS: Study supervision, study concept and design, critical revision of the manuscript. HF and SP: Drafting of the manuscript, critical revision of the manuscript for important intellectual content. RMSJ: Carried out the FISH assays, analysed the data and wrote the article. JRSN, CSS, KSC and FCS:
Carried out probes design, sample preparations and molecular analysis. All authors read and approved the final manuscript.

\section{Acknowledgments}

This project was conducted with support from the CNPq, FAPEAM and CAPES.

\section{Author details}

${ }^{1}$ Universidade do Estado do Amazonas, Manaus, Brazil. ${ }^{2}$ Fundação de Medicina Tropical Dr. Heitor Vieira Dourado, Manaus, Brazil. ${ }^{3}$ Department of Tropical Medicine at the Bernhard Nocht Institute, German Armed Forces Hospital of Hamburg, Hamburg, Germany. ${ }^{4}$ Institute of Medical Microbiology, Justus-Liebig-University Giessen, Giessen, Germany. ${ }^{5}$ Instituto de

Criminalística, Manaus, Brazil. ' Instituto Nacional de Pesquisas da Amazônia, Manaus, Brazil. ${ }^{7}$ Biotecnólogo/Tecnologista Pleno III, Instituto Nacional de Pesquisas da Amazônia, Coordenaação de Sociedade, Ambiente e Saúde, Laboratório de Micologia, Av. André Araújo, 2936, Aleixo, Manaus, AM CEP 69060-001, Brazil.

Received: 7 October 2014 Accepted: 18 January 2015

Published online: 31 January 2015 


\section{References}

1. Sifuentes-Osornio J, Corzo-León DE, Ponce-de-León LA. Epidemiology of invasive fungal infections in Latin America. Curr Fungal Infect Rep. 2012;6:23-34.

2. Armstrong-James $D$, Meintjes $G$, Brown GD. A neglected epidemic: fungal infections in HIV/AIDS. Trends Microbiol. 2014;22:120-7.

3. Leopoldina S, De Souza S, Vinícius P, Feitoza S, De Araújo JR. Causas de óbito em pacientes com síndrome da imunodeficiência adquirida, necropsiados na Fundação de Medicina Tropical do Amazonas Causes of death among patients with acquired immunodeficiency syndrome autopsied at the Tropical Medicine Foundation of Ama. Rev Soc Bras Med Trop. 2008;41:247-51.

4. Oliveira VCM, Saraceni V, Safe IP, Martins AG, Ramos TCA, Souza JVB, et al. Fatal Outbreak of Polyclonal Candidemia in a Neonatal Intensive Care Unit. Infect Control Hosp Epidemiol. 2014;35:1077-9.

5. Sangoi AR, Rogers WM, Longacre TA, Montoya JG, Baron EJ, Banaei N. Challenges and pitfalls of morphologic identification of fungal infections in histologic and cytologic specimens: a ten-year retrospective review at a single institution. Am J Clin Pathol. 2009;131:364-75.

6. Farina C, Perin S, Andreoni S, Conte M, Fazii P, Lombardi G, et al. Evaluation of the peptide nucleic acid fluorescence in situ hybridisation technology for yeast identification directly from positive blood cultures: an Italian experience. Mycoses. 2012;55:388-92.

7. Lass-Flörl C, Mutschlechner W, Aigner M, Grif K, Marth C, Girschikofsky M, et al. Utility of PCR in diagnosis of invasive fungal infections: real-life data from a multicenter study. J Clin Microbiol. 2013;51:863-8.

8. Guarner J, Brandt ME. Histopathologic diagnosis of fungal infections in the 21st century. Clin Microbiol Rev. 2011;24:247-80.

9. Lucignano B, Ranno S, Liesenfeld O, Pizzorno B, Putignani L, Bernaschi P, et al. Multiplex PCR allows rapid and accurate diagnosis of bloodstream infections in newborns and children with suspected sepsis. J Clin Microbiol. 2011;49:2252-8

10. Kempf VAJ, Trebesius K, Ingo B, Universita LM. Fluorescent In Situ Hybridization Allows Rapid Identification of Microorganisms in Blood Cultures Fluorescent In Situ Hybridization Allows Rapid Identification of Microorganisms in Blood Cultures. J Clin Microbiol. 2000;38:830-8.

11. Peters RPH, Savelkoul PHM, Alberdina M, Danner SA, Christina MJE, Van Agtmael MA, et al. Faster Identification of Pathogens in Positive Blood Cultures by Fluorescence In Situ Hybridization in Routine Practice Faster Identification of Pathogens in Positive Blood Cultures by Fluorescence In Situ Hybridization in Routine Practice. J Clin Microbiol. 2006;2011(46):119-23.

12. Lakner A, Essig A, Frickmann H, Poppert S. Evaluation of fluorescence in situ hybridisation (FISH) for the identification of Candida albicans in comparison with three phenotypic methods. Mycoses. 2012;55:e114-23.

13. Frickmann H, Lakner A, Essig A, Poppert S. Rapid identification of yeast by fluorescence in situ hybridisation from broth and blood cultures. Mycoses. 2012;55:521-31.

14. Martins ML, Ferreira AS, Sampaio A, Vieira R, Inácio J. Direct and specific identification of Cryptococcus neoformans in biological samples using fluorescently labelled DNA probes. Eur J Clin Microbiol Infect Dis. 2010;29:571-6.

15. Rickerts V, McCormick Smith I, Mousset S, Kommedal O, Fredricks DN. Deciphering the aetiology of a mixed fungal infection by broad-range PCR with sequencing and fluorescence in situ hybridisation. Mycoses. 2013;56:681-6

16. Hall L, Le Febre KM, Deml SM, Wohlfiel SL, Wengenack NL. Evaluation of the Yeast Traffic Light PNA FISH probes for identification of Candida species from positive blood cultures. J Clin Microbiol. 2012;50:1446-8.

17. Forrest GN, Mankes K, Jabra-Rizk MA, Weekes E, Johnson JK, Lincalis DP, et al. Peptide nucleic acid fluorescence in situ hybridization-based identification of Candida albicans and its impact on mortality and antifungal therapy costs. J Clin Microbiol. 2006;44:3381-3.

18. Reiss E, Shadomy HJ, Lyon GM. Laboratory Diagnostic Methods in Medical Mycology. Fundam. Med. Mycol. Hoboken, New Jersey: John Wiley \& Sons, Inc; 2011. p. 31-73.

19. Santos MS, Souza ES, Junior RMS, Talhari S, Souza JVB. Identification of fungemia agents using the polymerase chain reaction and restriction fragment length polymorphism analysis. Brazilian J Med Biol Res. 2010;43:712-6

20. Irobi J, Schoofs A, Goossens H. Genetic identification of Candida species in HIV-positive patients using the polymerase chain reaction and restriction fragment length polymorphism analysis of its DNA. Mol Cell Probes. 1999;13:401-6

21. Wang Y, Chen L, Liu X, Cheng D, Liu G, Liu Y, et al. Detection of Aspergillus fumigatus pulmonary fungal infections in mice with $(999 \mathrm{~m} \mathrm{~m}$ ) Tc-labeled MORF oligomers targeting ribosomal RNA. Nucl Med Biol. 2013;40:89-96.

22. Silva Jr R, Neto J, Santos C, Cruz K, Frickmann H, Poppert S, et al, Fluorescent in situ hybridization of preincubated blood culture material for the rapid diagnosis of histoplasmosis. Med Mycol. 2015;53:160-4.

23. Amann Rl, Krumholz L, Stahl DA. Fluorescent-oligonucleotide probing of whole cells for determinative, phylogenetic, and environmental studies in microbiology. J Bacteriol. 1990;172:762-70.

24. Kategaonkar AH, Pokalwar RU, Sonar SS, Gawali VU, Shingate BB, Shingare MS. Synthesis, in vitro antibacterial and antifungal evaluations of new alpha-hydroxyphosphonate and new alpha-acetoxyphosphonate derivatives of tetrazolo [1, 5-a] quinoline. Eur J Med Chem. 2010;45:1128-32.

25. Reller ME, Mallonee AB, Kwiatkowski NP, Merz WG. Use of peptide nucleic acid-fluorescence in situ hybridization for definitive, rapid identification of five common Candida species. J Clin Microbiol. 2007;45:3802-3.

26. Nosanchuk JD, Cleare W, Franzot SP. Amphotericin B and Fluconazole Affect Cellular Charge, Macrophage Phagocytosis, and Cellular Morphology of Cryptococcus neoformans at Subinhibitory Concentrations Amphotericin B and Fluconazole Affect Cellular Charge, Macrophage Phagocytosis, and Cell. Antimicrob Agents Chemother. 1999;43:233-9.

27. Sampaio IDL, Freire AKL, Ogusko MM, Salem Jl, De Souza JVB. Selection and optimization of PCR-based methods for the detection of Histoplasma capsulatum var. capsulatum. Rev Iberoam Micol. 2012;29:34-9.

28. Qian Q, Tang YW, Kolbert CP, Torgerson CA, Hughes JG, Vetter EA, et al: Direct identification of bacteria from positive blood cultures by amplification and sequencing of the 16s rrna gene: evaluation of bactec 9240 instrument true- positive and false-positive results direct identification of bacteria from positive blood cult. 2001: doi:10.1128/JCM.39.10.3578

29. Bisha B, Kim HJ, Brehm-Stecher BF. Improved DNA-FISH for cytometric detection of Candida spp. J Appl Microbiol. 2011;110:881-92.

30. Shepard JR, Addison RM, Alexander BD, Della-Latta P, Gherna M, Haase G, et al. Multicenter evaluation of the Candida albicans/Candida glabrata peptide nucleic acid fluorescent in situ hybridization method for simultaneous dual-color identification of C. albicans and C. glabrata directly from blood culture bottles. J Clin Microbiol. 2008;46:50-5.

\section{Submit your next manuscript to BioMed Central and take full advantage of:}

- Convenient online submission

- Thorough peer review

- No space constraints or color figure charges

- Immediate publication on acceptance

- Inclusion in PubMed, CAS, Scopus and Google Scholar

- Research which is freely available for redistribution

Submit your manuscript at www.biomedcentral.com/submit
C) Biomed Central 